Newfoundland and Labrador Studies

\title{
Lisa Moore. Something for Everyone
}

\section{Nathan R. Elliott}

Volume 34, Number 2, 2019

URI: https://id.erudit.org/iderudit/1072659ar

DOI: https://doi.org/10.7202/1072659ar

See table of contents

Publisher(s)

Faculty of Arts, Memorial University

ISSN

1719-1726 (print)

1715-1430 (digital)

Explore this journal

Cite this review

Elliott, N. (2019). Review of [Lisa Moore. Something for Everyone].

Newfoundland and Labrador Studies, 34(2), 341-344.

https://doi.org/10.7202/1072659ar viewed online.

https://apropos.erudit.org/en/users/policy-on-use/ 
Lisa Moore. Something for Everyone. Toronto: House of Anansi, 2018. ISBN 978-1-487-00116-2

In 2016, before a semi-literate trust fund brat somehow "won" the American election while losing the popular vote, and even before the United Kingdom was conned into committing economic suicide by a bunch of self-serving toffs, the government of Newfoundland and Labrador had already decided to wage economic war on its own citizens in the form of a hotly protested budget after finally being forced to admit that Muskrat Falls was a financial disaster. Better, said the Newfoundland government, to shut down libraries that served the rural poor and impose massive cuts on the people that educated their grandchildren than let a single corrupt politician or corporate manager face anything worse than an obscenely bloated golden parachute. For background noise, American mass shootings continued unabated, with the body count at an Orlando nightclub reaching a new record for gore; fears about global warming were the only distraction from a rising tide of global xenophobia.

Two years later, Lisa Moore has published Something for Everyone, a short story collection that feels like one of the more satisfying accounts of our era that I have read. In 2012 the late novelist Alistair Macleod told a university audience that fiction, in a very real sense, is simply an alternative form of news. Lisa Moore was a part of the discussion that night, and if her previous oeuvre didn't already demonstrate - especially her haunting exploration of the long-term cultural effects of the Ocean Ranger disaster in her novel February - that she practised a similar kind of journalism by other means, I would have said this collection suggested she was taking Macleod's advice. As I read the collection as a whole, my mind couldn't help but turn to landmark collections and individual stories that came in similarly turbulent times. Raymond Carver's What We Talk about When We Talk About Love and Cathedral gave us an emotional map to the economic desolation in the late 1970s and early 1980s in America; Franz Kafka's insect-minded travelling salesman gives us a glimpse into the racial and economic 
turbulence that would eventually lead to the Holocaust; Joyce's residents of Dublin suggest the divisions that would eventually explode into violence a few years later in the Irish War of Independence and the Irish Civil War a few years later. Something for Everyone, in its own way, provides an emotional guide to the way that economic austerity, rising nationalism, climate shock, and xenophobia have already reshaped our planet in violent and horrific ways, and gives us some sense of the horrors yet to come.

Moore's characters are the collateral damage of the economic fascism that has been imposed by the wealthy: economic violence continually threatens to erupt into physical violence in these stories. In the opening story, three very different characters struggle to make ends meet at a franchise athletic shoe store. A kind of odd solidarity is somehow achieved by story's end - a triumph over the absurdities of competition that capitalism drives us towards - and Moore earns her not quite happy, not quite despairing ending via an unflinching look at corporate exploitation and one of the more bizarre but convincing sex scenes I've read. Another story takes a gamble with a kind of magic realism that rarely comes off in stories for adults, as Santa Claus himself intervenes on behalf of a St. John's dishwasher. Not only does Moore make a Father Christmas tale not feel utterly saccharine, but she manages to use that character to underline a concept so poorly understood by the entitled and undeserving right-wing: moral luck. The concluding novella of the collection traces the long after-effects of a suicide and the immediate impact of a serial rapist, and both plot points feel like strong metaphors for the violence that informs so much of our collective culture.

I'm especially appreciative of the way that Moore guides sexual energy into the foundation of these stories: the thrum of sexual tension in this collection is real and unapologetic. Moore knows how to write assault and harassment, but she also understands lifelong love affairs, flirtation, the sexual longing of divorce and disability, and teenagers making out on an old couch at a kegger. Irish novelist Eimear McBride wrote for The Guardian that art with no sex left her a bit cold, 
and Moore's collection provides a partial answer as to why that might be. It might feel like a banal point that sex is a form of deep politics, but the force of Moore's characters gives her readers a chance to register that intellectual truth in our hearts and loins. Moore's sex is more than just sex - it's personal power dynamics and the way that the state's decisions inevitably shape our personal lives — but it's also pretty hot, and that potent combination of textual physicality and political subtext is difficult to beat.

A reviewer is obligated to find limitations, so I am told. Perhaps Moore gives into the temptation to use the literary fiction run-on a little often for my taste, but if I could routinely guide these page-long breathy utterances to safe harbour with the skill and grace she repeatedly demonstrates, I might be tempted do the same. Readers of Moore's previous work will already know that her prose tends to favour visual detail over many other aspects of fiction; her images remind me a bit of the better films of Terrence Malick. Like Days of Heaven or Tree of Life, these stories wash over you, and dialogue and plot sometime take a backseat to a striking image or cluster of images. And my response to this complaint might be in the same genre as the first: The Thin Red Line might not be everyone's keg of beer, but thank the gods that film's gorgeous self is out there, along with Moore's Something for Everyone.

With one notable exception, these stories are the stories of Newfoundlanders, and most of them are even more local than that: these are St. John's stories. That kind of focus on the local runs the risk of rendering a collection provincial, but in the hands of the right literary priest, local bread and a regional wine become universal sacraments. These might be Newfoundland stories, but they are also stories that might apply to an out-of-work Seattle factory worker gazing at the Amazon compound, an Irish real estate agent hit by yet another crash, or perhaps even a sweatshop worker in India serving global capitalism through the garment industry. William Carlos Williams's oft-cited quote about men dying from lack of poetry, however news-free it might be, comes to mind. We might not be able to get the news from 
literature, but perhaps sometimes we need good fiction to get our heads around the news. Moore's collection has captured this historical moment we find ourselves trying to survive.

Nathan R. Elliott

Montreal 